\title{
The Bi-Directional Relationship between Periodontal Disease and Hyperlipidemia
}

\author{
Ozlem Fentoglua
}

F. Yesim Bozkurt

\begin{abstract}
It has been proposed for several decades that infections may be responsible for the accelerated development of atherosclerosis. The initiation of the atherosclerotic plaque is ascribed to focal accumulation of lipids. This explains the importance of plasma lipids in the development of atherosclerosis. Recent reports point towards a possible association between periodontal disease and increased risk for cardiovascular disease. Thus, periodontitis and cardiovascular disease may share common risk factors, and association between periodontitis and coronary heart disease may be due to the elevated levels of plasma lipids. Epidemiological and clinical studies have also suggested that there is a relationship between periodontal disease and impaired lipid metabolism. In this review, we summarized the potential link mechanisms in the association between periodontal infection and serum lipids. (Eur J Dent 2008;2:142-149)
\end{abstract}

Key words: Periodontal disease; Hyperlipidemia; Lipid metabolism.

\section{INTRODUCTION}

Periodontal diseases are a group of inflammatory diseases in which Gram-negative microorganisms and their products are the principaletiologicagents. ${ }^{1}$ These microorganisms, particularly Porphyromonas gingivalis ( $P$. gingivalis), produce endotoxins in the form of

a Assist. Professor, Süleyman Demirel University, Faculty of Dentistry, Department of Periodontology, Isparta, Turkey

b Professor, Süleyman Demirel University, Faculty of Dentistry, Department of Periodontology, Isparta, Turkey.

- Corresponding author: Dr. Ozlem Fentoglu Suleyman Demirel Universitesi Dishekimligi Fakultesi, Periodontoloji Anabilim Dali, Dogu Kampusu, 32260, Isparta, Turkey.

Phone: + 902462113322 Fax : + 902462370607

E-mail: ofentogludyahoo.com lipopolysaccharides (LPS) that are instrumental in generating a host-mediated tissue destructive immune response. ${ }^{2}$ Recent studies indicate that periodontal disease may have profound effects on systemic health. Subjects with periodontal disease may have a higher risk for cardiovascular disease when compared to subjects with a healthy periodontium. ${ }^{3}$

The biological plausibility for a periodontal infection-systemic disease link can be briefly explained as follows. Periodontal infection causes bacteraemia and endotoxaemia and promotes systemic inflammatory and immune responses that may roles in systemic disease. Periodontal pathogens express specific virulence factors that can affect atherogenic events. Finally, periodontal pathogens have also been isolated from non-oral 
tissues like atheromatous plaques. ${ }^{4}$

The consequence of these findings, recent researches have been focused the association of periodontal infection and systemic disease, and in this relationship in the alterations of lipid metabolism have been revealed as a potentially inductive factor. ${ }^{5}$

\section{A. POTENTIAL MECHANISMS IN THE ASSOCIATION BETWEEN PERIODONTAL DISEASE AND HYPERLIPIDEMIA}

\section{Infection and hyperlipidemia}

Previously, it was thought that serum lipid alterations were related to the underlying pathological conditions rather than the infectious process. However, recent studies have demonstrated that lipid metabolism may be altered by chronic local and acute systemic infections which are involved in the plasma concentrations of unregulated cytokines and hormones. The main features of this catabolic state are lipid oxidation and elevated free fatty acids, triglycerides and low density lipoprotein (LDL) cholesterol.6,7

Studies in humans and animals have shown a number of cytokines such as tumor necrosis factor alpha (TNF- $\alpha$ ) and interleukin-1 beta (IL$1 \beta)$ are produced in response to systemic Gramnegative LPS exposure. It is believed that these cytokines exert effects on lipid metabolism by influencing production of other cytokines, altering hemodynamics/aminoacid utilization of various tissues involved in lipid metabolism, 8,9 or modifying the hypothalamic-pituitary-adrenal axis increasing plasma concentrations of adrenocorticotropic hormone, cortisol, adrenaline, noradrenaline, and glucagon. ${ }^{10-12}$ Thus, through action of TNF- $\alpha$ and IL-1 $\beta$, exposure to microorganisms/ endotoxin results in elevated levels of free fatty acids, LDL and triglyceride. These elevations in serum lipids are thought to arise from enhanced hepatic lipogenesis, ${ }^{13,14}$ increased adipose tissue lipolysis/blood flow, increased synthesis or reduced clearance of triglyceride, and reduced clearance of LDL due to reductions in lipoprotein lipase activity. ${ }^{15,16}$ Thus, any condition producing elevations in serum TNF- $\alpha$ and IL- $1 \beta$ has potential to cause hyperlipidemia.

Lipids may interact directly with the macrophage cell membrane, interfering with membrane-bound receptors and enzyme systems, altering macrophage gene expression for pro-inflammatory cytokines such as TNF- $\alpha$ and IL-1 $\beta$ and essential polypeptide growth factors such as platelet-derived growth factor (PDGF), transforming growth factor beta 1 (TGF$\beta 1$ ) and basic fibroblast growth factor (bFGF). ${ }^{17,18}$ Additionally, serum lipids, whether induced by diabetes, or diet increase polymorphonuclear leukocyte (PMN) production of pro-inflammatory cytokines and inhibit macrophage production of essential polypeptide growth factors impairing the wound healing process. Furthermore, hyperlipidemia may be more important than hyperglycemia relative to the hyper-responsive monosytic phenotype ${ }^{19-21}$ and development of many diabetic complications. ${ }^{22}$

2. Interactions between bacterial lipopolysaccharides and serum lipoproteins

a. Bacterial infections, lipoprotein levels and lipoprotein metabolism

The most commonly observed infectioninduced lipid abnormalities in man and experimental animals are increased triglyceride and very low density lipoprotein (VLDL) levels ${ }^{23}$ and decreased high density lipoprotein (HDL) cholesterol levels. ${ }^{24} \mathrm{~A}$ decrease in total and LDL cholesterol levels has also been reported during severe bacterial infections. ${ }^{25}$ However, in rodents and rabbits administration of LPS often leads to hypercholesterolemia. ${ }^{23}$ Hepatic and lipoprotein lipase activity levels decreased during acute infections. ${ }^{26,27}$

b. Abnormalities in lipid and lipoprotein levels: cytokine mediated effects

Tumor necrosis factor (TNF) induces a rapid increase in serum triglyceride, VLDL and cholesterol levels. Although the mechanism by which TNF increases serum cholesterol levels is unknown, the increase in hepatic cholesterol synthesis may be due to an increase in the activity of 3-hydroxy-3-methyl glutaryl coenzyme A (HMG-CoA) reductase. ${ }^{13}$

c. LPS-LDL interactions: effects on lipoprotein metabolism

Low concentrations of LPS inhibit the 
expression of scavenger receptor activity on human monocyte-derived macrophages but had no effect on LDL receptor activity. ${ }^{28}$ Furthermore, when LPS is complexed with LDL the inhibitory effect of LPS on scavenger receptor activity is markedly enhanced. ${ }^{29}$ Besidesaffecting scavenger and LDL receptors, LPS affects LDL metabolism by precluding its hydrolysis. Furthermore, LPS binds to lipoproteins in direct proportion to their cholesterol content and that the LDL-LPS complex once taken by macrophages is not degraded. ${ }^{29}$

d. LPS, release of cytokines and LDL modification

Though it was demonstrated that LPS causes widespread endotelial damage, in hypercholesterolemic status this damage seems to be more severe and persistent. ${ }^{30}$ In animals maintained on high cholesterol diets for the duration of the experiment, arteriosclerotic lesions may not be detectable until 3 months after administration of a single small dose of LPS, even so, LPS cause the initial endothelial damage, and hypercholesterolemia may interrupt the normal repair process. ${ }^{31}$

Another possible mechanism by which LPS contributes to the development of atherosclerosis is the oxidative modification of LDL induced during macrophage activation. Several possible pathogenic roles with marked importance in the development of atherosclerosis may be attributed to oxidized LDL (ox-LDL). First, ox-LDL is taken up by macrophage scavenger receptors ${ }^{32,33}$ leading to the transformation of macrophages into foam cells, the hallmark of the atherosclerotic process. Second, ox-LDL is cytotoxic for endothelial cells ${ }^{34}$ and is a potent chemo-attractant for circulating human monocytes. ${ }^{33}$

\section{Lipoprotein-associated inflammatory} proteins: mediators of cardiovascular disease

Plasma lipoproteins are largely involved in the transport of acute phase reactant proteins such as $\mathrm{C}$-reactive protein (CRP), serum amyloid $A$ and secretory phospholipase $A_{2}$ which greatly increases the risk of atherosclerosis. ${ }^{35}$

The acute phase reactions, associated with injury, inflammation, or sepsis, markedly affect the concentration and composition of plasma lipids and lipoproteins. Hepatic production of triglycerides and LDL formation are increased, but do not necessarily result in high plasma triglyceride levels. In contrast, all conditions lower plasma cholesterol by decreasing its content in both low-density and high-density lipoproteins. In addition, substantial changes in protein and lipid composition of lipoproteins are observed that may redefine the function of these particles, but also increase their atherogenic and inflammatory properties. ${ }^{36}$

\section{Modulatory effects of dietary lipids on} immune system functions

The immune response of both humans and animals may be influenced by several essential nutrients, which modify the immune system functions. Dietary lipids or free fatty acids may be modulate the immune system through a great number of mechanisms that include reduction of lymphocyte proliferation, reduction of cytokine synthesis, increase of phagocytic activity,modification of natural killer (NK) cell activity and so on. This modulation may be associated with changes in the cell membrane due to dietary fatty acid manipulation. Fatty acids may be incorporated into the plasma membrane after dietary lipid administration, so that the composition of lipids in this cellular structure will reflect the composition of dietary lipids. ${ }^{37}$ Because of this incorporation, the phospholipid profiles associated with plasma membrane of lymphocytes, monocytes/macrophages or polymorphonuclear cells may be altered by dietary lipids. ${ }^{38,39}$

Diets including polyunsaturated fatty acids, such as eicosapentaenoic or docosahexaenoic acids, suppress the mitogenic response of lymphocytes to a greater extent than diets rich in saturated fatty acids. ${ }^{40}$

Fatty acids may regulate cytokine production and in fact cytokine modulation by fatty acids seems to be responsible for the reduction of lymphocyte proliferation in both animals and humans. Cytokines such as IL-1 and TNF are important mediators of inflammation and dietary fatty acids have been demonstrated to be substances capable of reducing the pro-inflammatory response induced by IL-1 and TNF.41-43 The mechanisms involved in the modification of cytokine synthesis remain unclear as yet, but a possible explanation could be found 
in the regulation at the transcriptional level, that is, reduction of cytokine mRNA production by polyunsaturated fatty acids. ${ }^{44}$ Dietary fatty acids may also be able to modulate activity of NK cells participating in protection against virus, intracellular bacteria or tumoral cells. Diets containing fish oil or olive oil produce the greatest percentage of NK cell activity inhibition in comparison with diets rich in saturated fatty acids or n-6 polyunsaturated fatty acids. ${ }^{45,46}$ However, there are several reports are found, eicosanoids such as prostaglandins, leukotrienes or lipoxins may play important role in this mechanism. ${ }^{47-49}$ It has been reported that unsaturated fatty acids increase phagocytosis which is an important mechanism in many cells for the elimination of microorganisms or foreign particles. ${ }^{42,50}$

Mechanisms involved in fatty acid modulation are membrane fluidity, production of lipid peroxides, eicosanoid synthesis and influence on gene regulation. As a result of changes in the phospholipids fatty acid composition due to dietary lipid manipulation, the fluidity of the cell membrane may change. Fatty acids have inhibitory effects on cellular proliferation due to lipid peroxidation which are toxic to cells. Dietary fats have an important role in decreasing antioxidant enzyme mRNA levels and enhancing free radical-induced tissue damage. Fatty acids undergo enzymatic degradation to yield eicosanoid family (prostaglandins, leukotrienes or lipoxins) participating in inflammatory processes and are also related to immunomodulatory effects, which act as lipid mediators. ${ }^{51}$

\section{B. PERIODONTITIS AND HYPERLIPIDEMIA}

The alterations in immune cell phenotype due to serum lipids and elevation in serum pro-inflammatory cytokines such as TNF-a and IL-1 $\beta$ through periodontitis as a chronic gram (-) infection verified substantial evidences supporting this bidirectional relationship.

Hyperlipidemia, arising from a high-fat diet or metabolic disorders such as type 2 diabetes, has a dysregulatory effect on immune system cells and on wound healing and as a result, it increases the susceptibility to periodontitis and other infections. This condition needs a particular threshold level of circulating lipids for every individual, above which can lead to this dysregulatory effect within the gingival mucosa and elsewhere. ${ }^{5}$

It has been reported that consumption of a typical high-fat American breakfast (fried eggs, bacon, potatoesl or a defined saturated-fatrich meal (i.e. ice cream) leads to functional abnormalities in PMNs. ${ }^{52}$ A protective role for PMNs in the early response to periodontal infection is supported by compelling experiments in nature, wherein subjects with impairments of PMN function ${ }^{53}$ or number ${ }^{54}$ have more acute and severe periodontitis. So, PMNs primed by endotoxin or other activating agents, including dietary lipids may play a major role in the pathogenesis of periodontitis. ${ }^{55} \mathrm{~A}$ possible role of hyperlipidemia for periodontitis is also obvious from several studies. Hyperlipidemia is known to cause a hyperactivity of white blood cells. ${ }^{56,57}$ Hyperactivity of white cells, e.g., increased production of oxygen radicals, have been shown to be frequently associated with progressive periodontitis in adults. ${ }^{58}$ In animals feeding a cholesterol-rich diet have caused to periodontitis. ${ }^{59}$

In an animal model, Maglakelidze et al $^{60}$ have reported significant changes in extracellular matrix and gingival mucous cells as well as in microcirculatory bed components in hypercholesterolemia. Hypercholesterolemia damages endotheliocytes, subendothelial zone and basal membrane permeability. The contact of lymphocytes and plasmocytes with the vascular wall confirms the trigger role of the vascular factor in damaging of periodontal complex.

There are several studies which report significant association between plasma lipid levels and the severity of the periodontal disease. ${ }^{61-63}$ While some authors mentioned that there were significant correlations between periodontal status and cholesterol levels, ${ }^{64-69}$ others indicate that there were significant associations between triglyceride level and periodontal disease. ${ }^{70-72}$

Thestudieswhich trying the effect of periodontal therapy on serum lipids and lipoprotein associated inflammatuar mediators ${ }^{73-76}$ also suggested that the treatment of periodontal disease have beneficial effects on lipid metabolism. In one study conducted in systemically healthy subjects with periodontitis, Pussinen et $\mathrm{al}^{73}$ stated that periodontitis is associated with macrophage 
activation via increased serum LPS concentration. Additionally, there was a significant increase in the ratio of HDL/LDL after periodontal treatment in this study. In another study, Pussinen et $\mathrm{al}^{74}$ reported that there were statistically significant decreases in CRP and serum amyloid A levels after periodontal treatment in systemically healthy subjects with periodontitis. That study also suggested that periodontitis diminishes the anti-atherogenic potency of HDL and increase the risk for coronary heart disease.

Lösche et al $^{75}$ evaluated 32 patients with moderate to severe periodontitis before and 3 months after local periodontal treatment and they reported that treatment of periodontitis caused a significant reduction in the serum activity of lipoprotein-associated phospholipase $A_{2}$ which is believed to be an independent cardiovascular risk factor. In a similar study, 65 subjects presenting with severe lprobing pocket depth greater than $6 \mathrm{~mm}$ and marginal alveolar bone loss greater than $30 \%$ ), generalized lat least $50 \%$ of teeth affected) periodontitis were assessed and the 3 groups consisted of untreated control; standard periodontal therapy; and an intensive periodontal treatment including standard periodontal treatment with adjunctive local delivery of minocycline. In that study both standard periodontal therapy and intensive periodontal therapy resulted in significant reductions in serum CRP compared with the untreated control and the intensive periodontal therapy group also showed a decrease in total and LDL cholesterol after 2 months following the periodontal treatment. ${ }^{76}$

Higher serum levels of total cholesterol, LDL-C and triglycerides have been found in subjects with periodontal disease, ${ }^{71,77,62}$ and hyperlipidemic patients have a significantly higher percentage of sites with probing depth greater than $3.5 \mathrm{~mm}$ than subjects with normal metabolic status. ${ }^{78}$ The interrelationship between periodontitis and hyperlipidemia provides an example for systemic disease predisposing to oral infection, and once the oral infection is established, it exacerbates systemic disease.

\section{CONCLUSIONS}

However, it is unclear whether the association of periodontal disease and impaired lipid metabolism is a cause-effect interrelationship, namely whether periodontitis induces higher serum lipid levels or higher serum lipid levels are predisposing factors for periodontitis, the association of these two phenomenons is widely discussed in the periodontal literature.

\section{REFERENCES}

1. Listgarten MA. Nature of periodontal diseases: Pathogenic mechanisms. J Periodont Res 1987;22:172-178.

2. Cutler CW, Kamlar JR, Genco CA. Pathogenic strategies of the oral anaerobe, Porphyromonas gingivalis. Trends Microbiol 1995;3:45-51.

3. Mattila KJ, Nieminen MS, Valtonen, VV, Rasi VP, Kesaniemi YA, Syrjala SL. Association between dental health and acute myocardial infarction. BMJ 1989;298:779-781.

4. Paquette DW. The periodontal infection-systemic disease link: A review of the truth or myth. $J$ Int Acad Periodontol 2002;4:101-109.

5. lacopino AM, Cutler CW. Pathophysiological relationships between periodontitis and systemic disease: Recent concepts involving serum lipids. J Periodontol 2000;71:13751384.

6. Lopes-Virella MF. Interactions between bacterial lipopolysaccharides and serum lipoproteins and their possible role in coronary heart disease. Eur Heart $J$ 1993;14:118-124.

7. Samra JS, Summers LKM, Frayn KN. Sepsis and fat metabolism. Br J Surg 1996;83:1186-1196.

8. Fukushima R, Saito H, Taniwaka K. Different roles of IL-1 and TNF on hemodynamics, amino acid metabolism in dogs. Am J Physiol 1992;262:275-281.

9. Van der Poll T, Romijn JA., Endert E, Borm JJ, Buller HR, Sauerwein HP. Tumor necrosis factor mimics the metabolic response to infection in healthy humans. Am J Physiol 1991;261:457-465.

10. Gwosdow AR, Kumar MSA, Bode HH. Interleukin-1 stimulation of the hypothalamic-pituitary-adrenal axis. Am J Physiol 1990; 258:65-70.

11. Imura H, Fukata J, Mori T. Cytokines and endocrine function: an interaction between the immune and neuroendocrine systems. Clin Endocrinol 1991;35:107-115.

12. Chrousos GP. The hypothalamic-pituitary-adrenal axis and immune-mediated inflammation. $N$ Engl $J$ Med 1995;332:1351-1362.

13. Feingold KR, Grunfeld C. Tumor necrosis factor alpha stimulates hepatic lipogenesis in the rat in vivo. $J$ Clin Invest 1987;80:184-190.

14. Kurpad A, Khan K, Calder AG. Effect of noradrenaline on glycerol turnover and lipolysis in the whole body and subcutaneous adipose tissue. Am J Physiol 1992;263:850- 
855.

15. Lanza-Jacoby S, Tabares A. Triglyceride kinetics, tissue lipoprotein lipase, and liver lipogenesis in septic rats. $\mathrm{Am}$ J Physiol 1990;258:678-685.

16. Fried SK, Zechner R. Tumor necrosis factor decreases human adipose tissue lipoprotein lipase mRNA levels, synthesis, and activity. J Lipid Res 1989;30:1917-1923.

17. Doxey DL, Ng, MC, Dill RE, lacopino AM. Platelet-derived growth factor levels in wounds of diabeticrats. Life Sci 1995;57:1111-23.

18. Chu X, Newman J, Park B, Nares S, Ordonez G, lacopino AM. In vitro alteration of macrophage phenotype and function by serum lipids. Cell Tissue Res 1999;296:331-337.

19. Craig TE, Jackson RL, Ohlweiler DF, Ku G. Multiple lipid oxidation products in low density lipoproteins induce interleukin-1 beta release from human blood mononuclear cells. J Lipid Res 1994;35:417-427.

20. Van der Poll T, Braxton CC, Coyle SM, Calvano SE, Hack $C E$, Lowry SF. Effect of hypertriglyceridemia on endotoxin response in humans. Infect Immun 1995;63:3396-4000.

21. Jovinge $S$, Ares M, Kallin B, Nilsson J. Human monocytes/ macrophages release TNF- $\alpha$ in response to ox-LDL. Arterioscler Thromb Vasc Biol 1996;16:1573-1579.

22. Dutta-Roy AK. Insulin mediated processes in platelets, erythrocytes and monocytes/macrophages: effects of essential fatty acid metabolism. Prostaglandins Leukot Essent Fatty Acids 1994;51:385-399.

23. Cabana VG, Siegel JW, Sabesin SM. Effects of the acute phase response on the concentration and density distribution of plasma lipids and apolipoproteins. J Lipid Res 1989;30:39-49.

24. Kerttula Y, Vaara M, Phyhälä L. Effect of bacterial lipopolysaccharide on serum high density lipoprotein cholesterol in rabbits. Atherosclerosis 1984;52:123-126.

25. Akerlund B, Carlson LA, Jarstrand C. Dyslipoproteinemia in patients with severe bacterial infections. Scand J Infec Dis 1986;18:539-545.

26. Alvarez C, Ramos A. Lipids, lipoproteins, and apoproteins in serum during infection. Clin Chem 1986;32:142-145.

27. Sammalkorpi K, Valtonen V, Kerttula Y, Nikkila E, Taskinen MR. Changes in serum lipoprotein pattern induced by acute infections. Metabolism 1988;37:859-865.

28. Van Lenten BJ, Fogelman AM, Seager J, Ribi E, Haberland ME, Edwards PA. Bacterial endotoxin selectively prevents the expression of scavenger receptor activity on human monocyte-macrophages. J Immunol 1985;134:3718-3721.

29. Van Lenten BJ, Fogelman AM, Haberland ME, Edwards PA. The role of lipoproteins and receptor-mediated endocytosis in the transport of bacterial lipopolysaccharide. Proce Natl Acad Sci USA 1986;83:2704-2708.
30. Reidy MA, Bowyer DE. Distortion of endthelial repair. The effect of hypercholesterolemia on regeneration of aortic endothelium following injury by endotoxin. Atherosclerosis 1978;29:459-466.

31. Nam SC, Lee WM, Jarmolych J, Lee KT, Thomas WA. Rapid production of advanced atherosclerosis in swine by a combination of endothelial injury and cholesterol feeding. Exp Mol Pathol 1973;18:369-379.

32. Yla-Herttuala S. Macrophages and oxidized low density lipoproteins in the pathogenesis of atherosclerosis. Ann Med 1991;23:561-567.

33. Witztum JL, Steinberg D. Role of oxidized low density lipoprotein in atherogenesis. J Clin Invest 1991;88:17851792.

34. Cathcart MK, McNally AK, Morel DW, Chisolm GM. The role of superoxide anion in human monocyte-mediated oxidation and conversion of LDL to a cytotoxin. J Immunol 1988;142:1963-1969.

35. Chait A, Han CY, Oram JF, Heinecke JW. Lipoproteinassociated inflammatory proteins: markers or mediators of cardiovascular disease? J Lipid Res 2005;46:389-403.

36. Carpentier YA, Scruel O. Changes in the concentration and composition of plasma lipoproteins during the acute phase response. Curr Opin Clin Nutr Metab Care 2002;5:153-158.

37. Clamp AG, Ladha S, Clark DC, Grimble RF, Lund EK. The influence of dietary lipids on the composition and membrane fluidity of rat hepatocyte plasma membrane. Lipids 1997;32:179-184.

38. Tiwary RK, Clandinin MT, Cinader B et al. Effect of high polyunsaturated fat diets on the composition of $\mathrm{B}$ cell and T cell membrane lipids. Nutr Res 1987;7:489-498.

39. Chapkin TS, Carmichael SL. Effects of dietary n-3 and n-6 polyunsaturated fatty acid on macrophage phospholipids classes and subclasses. Lipids 1990;25:827-834.

40. Calder PC. Fatty acids, dietary lipids and lymphocyte functions. Biochem Soc Trans 1995;23:302-309.

41. Endres S, Ghorbani R, Kelley VE et al. The effect of dietary supplementation with $n-3$ polyunsaturated fatty acids on the synthesis of interleukin-1 and tumor necrosis factor by mononuclear cells. N Engl J Med 1989;320:265-271.

42. De Pablo MA, Ortega E, Gallego AM, Alvarez C, Pancorbo $P L$, Alvarez de Cienfuegos $G$. The effect of dietary fatty acid manipulation on phagocytic activity and cytokine production by peritoneal cells from Balb/c mice. J Nutr Sci Vitaminol 1998;44:57-67.

43. Endres S. N-3 polyunsaturated fatty acids and human cytokine synthesis. Lipids 1996;31:S239-242.

44. Robinson DR, Urakaze M, Huang R et al. Dietary marine lipids suppress continuous expression of interleukin-1 $\beta$ gene expression. Lipids 1996;31:S23-31. 
45. De Pablo MA, Ortega E, Gallego AM, Alvarez C, Pancorbo PL, Alvarez de Cienfuegos G. Influence of diets containing olive oil, sunflower oil or hydrogenated coconut oil on the immune response of mice. J Clin Biochem Nutr 1998;25:1123.

46. Yaqoob P, Newsholme EA, Calder PC. Inhibition of natural killer cell activity by dietary lipids. Immunol Lett 1994;41:241247.

47. Roder JC, Klein M,. Target-effector interaction in the natural killer cell system. J Immunol 1979;123:2785-2790.

48. Bray RA, Brahmi Z. Role of lipooxygenation in natural killer cell activation. J Immunol 1986;136:1783-1790.

49. Ramstedt U, Ng J, Wigzell H, Serhan CN, Samuelsson B. Action of novel eicosanoids lipoxin $A$ and $B$ on human natural killer cell cytotoxicity. Effects on intracellular CAMP and target cell binding. J Immunol 1985; 135:3434-3438.

50. Calder PC, Bond JA, Harvey DJ, Gordon S, Newsholme EA. Uptake and incorporation of saturated and unsaturated fatty acids into macrophage lipids and their effect upon macrophage adhesion and phagocytosis. Biochem $J$ 1990;269:807-814.

51. De Pablo MA, De Cienfuegos GA. Modulatory effects of dietary lipids on immune system functions. Immunol Cell Biol 2000;78:31-39.

52. Uhlinger DJ, Burnham DN, Mullins RE, Kalmar JR, Cutler CW, Arnold RR, Lambeth JD, Merrill Jr AH. Functional differences in human PMNs isolated pre- and postprendially. FEBS Lett 1991;286:28.

53. Van Dyke TE, Hosozewicz HV, Cianciola LJ, Genco RJ. Neutrophil chemotaxis dysfunction in human periodontitis. Infect Immun 1980;27:124-132.

54. Cohen DW, Morris AL. Periodontal manifestations of cyclic neutropenia. J Periodont Res 1961;32:159-168.

55. Cutler CW, Wasfy MO, Ghaffar K, Hosni M, Bloyd DR. Impaired bactericidal activity of PMN from two brothers with necrotizing ulcerative gingivo-periodontitis. $J$ Periodontol 1993;65:357-363.

56. Croft KD, Beilin LJ, Vandongen R, Rouse I, Masarei J. Leukocyte and platelet function and eicosanoid production in subjects with hypercholesterolaemia. Atherosclerosis 1990; 83:101-109.

57. Krause S, Pohl A, Pohl C, Liebrenz A, Ruhling K, Losche $W$. Increased generation of reactive oxygen species in mononuclear blood cells from hypercholesterolemic patients. Thromb Res 1993;71:237-240.

58. Krause S, Brachmann P, Brandes C, Losche W, Hoffmann T, Gangler P. Aggregation behavior of blood granulocytes in patients with periodontal disease. Arch Oral Biol 1990; 35:75-77.

59. Ueno K. Histological studies on the Wistar rats fed cholesterol, sodium cholate and methylthiouracil, with special reference to the changes of the periodontal tissues. Kokubyo Gakkai Zasshi 1965;32:368-91.

60. Maglakelidze N, Galogre A, Tsagareli Z. Functionalmorphologic aspects of changes of mucosal gingiva microcirculatory bed vessels in experimental gingivitis against the background of hypercholesterolemia. Georgian Med News 2005;4:71-74.

61. Ebersole JL, Cappelli D, Mott GE, Kesavalu L, Holt SC, Singer RE. Systemic manifestations of periodontitis in the non-human primate. J Periodont Res 1999;34:358-362.

62. Lösche W, Karapetow F, Pohl A, Pohl, C, Kocher T. Plasma lipid and blood glucose levels in patients with destructive periodontal disease. J Clin Periodontol 2000a;27:537-541.

63. Lösche W, Karapetow F, Pohl A, Krause S, Kocher T. Plasmalipide, blutglucose und PAF-Acetylhydrolase bei marginaler paradontitis. Deutsche Zahnärztliche Zeitschrift 2000b;55:431-434.

64. Johansson I, Tidehag P, Lundberg V, Hallmans G. Dental status, diet and cardiovascular risk factors in middle-aged people in northern Sweden. Community Dent Oral Epidemiol 1994;22:431-436.

65. Wakai K, Kawamura T, Umemura O, Hara Y, Machida J, Anno T, Ichihara Y, Mizuno Y, Tamakoshi A, Lin Y, Nakayama T, Ohno Y. Associations of medical status and physical fitness with periodontal disease. J Clin Periodontol 1999;26:664672.

66. Wu T, Trevisan M, Genco RJ, Falkner KL, Dorn JP, Sempos CT. Examination of the relation between periodontal health and cardiovascular risk factors: Serum total and high density lipoprotein cholesterol, C-reactive protein, and plasma fibrinogen. Am J Epidemiol 2000a;121:273-282.

67. Katz J Chaushu G, Sharabi V. On the association between hypercholesterolemia, cardiovascular disease and severe periodontal disease. J Clin Periodontol 2001;28:865-868.

68. Katz J, Flugelman MY, Golberg A, Heft M. Association between periodontal pockets and elevated cholesterol and low density lipoprotein cholesterol levels. J Periodontol 2002;73:494-500.

69. Buhlin K, Gustafson A, Pockley AG, Frostegard J, Klinge B. Risk factors for cardiovascular disease in patients with periodontitis Eur Heart $J$ 2003;24:2099-2107.

70. Morita M, Horiuchi M, Kinoshita Y, Yamamato T, Watanabe T. Relationship between blood triglyceride levels and periodontal status. Community Dent Health 2004;21:32-36.

71. Cutler CW, Shinedling EA, Nunn M, Jotwani R, Kim B, Nares S, lacopino AM. Association between periodontitis and hyperlipidemia: cause or effect? $J$ Periodontol 1999b;70:1429-1434.

72. Uchiumi D, Kobayashi M, Tachikawa T, Hasegawa 
K. Subcutaneous and continuous administration of lipopolysaccharide increases serum levels of triglyceride and monocyte chemoattractant protein- 1 in rats. J Periodont Res 2004;39:120-128.

73. Pussinen PJ, Jauhiainen M, Vilkuna-Rautiainen T, Sundvall J, Vesanen M, Mattila K, Palosuo T, Alfthan G, Asikainen S. Severe periodontitis enhances macrophage activation via increased serum lipopolysaccharide. Arterioscler Thromb Vasc Biol 2004;24:2174-2180.

74. Pussinen PJ, Jauhiainen M, Vilkuna-Rautiainen T, Sundvall J, Vesanen M, Mattila K, Palosuo T, Alfthan G, Asikainen S. Periodontitis decreases the antiatherogenic potency of high density lipoprotein. J Lipid Res 2004;45:139-147.

75. Lösche W, Marshai GJ, Apatzidou DA, Krause S, Kocher T, Kinane DF. Lipoprotein-associated phospholipase A2 and plasma lipids in patients with destructive periodontal disease. J Clin Periodontol 2005;32:640-644.

76. D'aiuto F, Nibali L, Parkar M, Suvan J, Tonetti MS. Short-term effects of intensive periodontal therapy on serum inflammatory markers and cholesterol $J$ Dent Res 2005;84:269-273.

77. Cutler CW, Machen RL, Jotwani R, lacopino AM. Heightened gingival inflammation and attachment loss in type 2 diabetics with hyperlipidemia. J Periodontol 1999a;70:13131321.

78. Noack B, Jachmann I, Roscher S, Sieber L, Kopprasch S, Luck, C, Hanefeld M, Hoffmann T. Metabolic diseases and their possible link to risk indicators of periodontitis. $J$ Periodontol 2000;71:898-903. 